\title{
Chemical Characteristics and Activity of ACE Inhibitors on Fractionation of Tempeh Koro kratok (Phaseolus lunatus) Peptides
}

\author{
Marta Tika Handayani ${ }^{1)}$, Retno Indrati ${ }^{1)}$, Muhammad Nur Cahyanto ${ }^{1)}$ \\ 1) Departement of Food and Agricultural Product Technology, Faculty of Agricultural Technology, Universitas Gadjah Mada, \\ Jl. Flora, Bulaksumur, Yogyakarta 55281, Indonesia. \\ ${ }^{*}$ Correspondence Email: indrati@ugm.ac.id
}

\begin{abstract}
Tempeh is a fermented food that is good for health and has high nutritional value. Koro kratok tempeh is one of tempeh which is made from non-soybean legumes. The fermentation process will convert macromolecular compounds to micromolecules thereby increasing bioavailability and providing functional properties. This study aimed to find out the chemical properties of koro kratok tempeh and the effect of peptide molecular weight of koro kratok tempeh on ACE inhibition activity. The results show that koro kratok seeds contained $20.66 \%$ protein which total hydrophobic amino acid was $3.32 \%$ (w/w protein). This hydrophobic amino acid was higher than that soybean, indicated that koro kratok (Phaseolus lunatus) has a potential producing ACE peptide inhibitors. The koro kratok seeds had ACE inhibitory activity $19.72 \%$. This activity increased to $84.97 \%$ when the seeds were fermented for $48 \mathrm{~h}$ to become tempeh. Peptide fractionation showed that the smaller the molecular weight of the peptide, the higher the ACE inhibitory activity.
\end{abstract}

Keywords: Tempeh, koro kratok, ACE-inhibitor, peptide

\section{INTRODUCTION}

Tempeh is fermented foods that popular to many people in the Java region, because of its unique taste and its nutrients. The fermentation process during tempeh production will increase bioavailability. Tempeh fermentation involves microbes, such as Rhizopus oligosphorus, and others.

Rhizopus oligosphorus is a type of mold that is commonly found in tempeh fermentation. Besides Rhizopus oligosphorus, Rhizopus oryzae also found during tempeh fermentation (Nout and Kiers, 2005). Rhizopus oligosphorus excretes protease with a higher proteolytic activity than other molds (Karmini et al., 1996). Besides that, Rhizopus oligosphorus also excretes lipase and amylase. These enzymes play a role in cutting long-chain carbohydrates, fat, and protein into shorter chains, so that the digestibility increases.

Tempeh that is sold in the market is made from soybeans. Other materials that commonly used are koro-koroan, such as koro kratok (Phaseolus lunatus). The koro kratok is a type of koro bean that originates from Central America and South America. Koro kratok is also found in Indonesia, especially East Java and Madura. The productivity of koro kratok in Indonesia reaches 2-8 tons of fresh seeds/ ha depending on the type of cultivar and cultivation conditions. In the tropics, koro kratok has productivity of $200-600 \mathrm{~kg} / \mathrm{ha}$ (in intercropping), or 1-1.5 tons/ha (single cropping),. In cultivated plants, productivity reaches 2-4 tons/ha (Baudoin, 2006).

Koro kratok is known to have a high protein content, which is around 17 to 29\% (Budi et al., 2003). Magana et al., 2015 stated that the amino acids contained in the koro kratok (P. lunatus) hydrolyzate were Asx, Glx, Ser, His, Gly, Thr, Arg, Ala, Pro, Tyr, Val, Met, Cys, Ile, Leu, Phe, Lys, Trp. Tejasari (2009) states that the essential amino acids found in the koro kratok consist of phenylalanine, tyrosine, threonine, tryptophan, valine, isoleucine, leucine and lysine. Other studies on koro kratok concluded that koro kratok hydrolyzate has the potential to produce ACE inhibitor bioactive peptides. So the purpose of this study was to find out the chemical characteristics of koro kratok tempeh and the effect of peptide molecular weight on ACE inhibitory activity.

\section{MATERIALS AND METHODS}

\section{Material}

The research raw materials used were koro kratok (Phaseolus lunatus L.) originating from Madura, Raprima brand tempeh inoculum. Chemicals: $\mathrm{NaCl}, \mathrm{CaCO}_{3}, \mathrm{NaOH}$, $\mathrm{HCl}, \mathrm{K}_{2} \mathrm{SO}_{4}, \mathrm{Na}_{2} \mathrm{~S}_{2} \mathrm{O}_{3}, \mathrm{Na}_{2} \mathrm{CO}_{3}, \mathrm{CuSO}_{4} .5 \mathrm{H}_{2} \mathrm{O}, \mathrm{TCA}$, distilled water, colic acid, sodium taurocholate, sodium deoxycholate, ethyl acetate, $\mathrm{NaCl}, \mathrm{AgNO}_{3}$ and $\mathrm{NH}_{4} \mathrm{OH}$, were analytical grade.

\section{Sample preparation}

Koro kratok tempeh was prepared by boiling the beans for $30 \mathrm{~min}$, then soaked for $12 \mathrm{~h}$. After that, the epidermis skins were removed and the beans were soaked again for $24 \mathrm{~h}$ (water replacement every $12 \mathrm{~h}$ ). Finally, these beans were boiled for $15 \mathrm{~min}$ before inoculated with raprima inoculum. Fermentation was done for $48 \mathrm{~h}$ of incubation at room temperature.

\section{Peptide Extraction}

Peptide extraction was carried out by the method of Mechin et al. (2007) and LuoAs et al. (2016) with a ratio between $1 \mathrm{~g}$ powdered tempeh mixed with $30 \mathrm{ml}$ aquabides. This mixture was extracted using blender for $3 \mathrm{~min}$ at $8000 \mathrm{rpm}$, then Incubated on waterbath at $30^{\circ} \mathrm{C}, 60 \mathrm{rpm}$ for $60 \mathrm{~min}$ and the supernatant was collected after centrifugation at $20,000 x g$ for $15 \mathrm{~min}$. 


\section{Proximate Analysis}

The protein, fat, water, and ash content were measured using the methods of AOAC (2005), whereas carbohydrate content was calculated by difference.

\section{Analysis of Amino Acid Composition}

Amino acid compositions of the koro kratok protein were analyzed using LC-MS/MS. The sample was hydrolyzed using $6 \mathrm{~N} \mathrm{HCl}$ then heated using autoclave $110^{\circ} \mathrm{C}$ for 12 hours. The samples were neutralized using $6 \mathrm{~N} \mathrm{NaOH}$ and filtered using a $0.22 \mu \mathrm{m}$ siring filter and diluted with aquabides with a ratio of 1:50 (v/v). Two $\mu$ of the sample was injected into the LS-MS/MS (The Water Xevo TQD, Waters, USA). The solvents used are: solvent A: $0.1 \%$ pentadecafluoroactanoat acid:water/ $\mathrm{CH}_{3} \mathrm{CN}$ with $0.1 \%$ formic acid $=99.5 \%: 0.5 \%$ and solvent $\mathrm{B}$ composed of $0.1 \%$ pentadecafluorooctanoat acid:water $/ \mathrm{CH}_{3} \mathrm{CN}$ with $0.1 \%$ formic acid $=10 \%: 90 \%$. The sample was eluted at a temperature of $50^{\circ} \mathrm{C}$ for $1.5 \mathrm{~min}$ in solvent $\mathrm{A}$ and $0.5 \mathrm{~min}$ in solvent $\mathrm{B}$ with a flow rate of $0.6 \mathrm{ml} /$ minute.

\section{ACE Inhibitory Activity}

The ACE inhibitor activity of the hydrolyzate was measured by a UV spectrophotometer based on the rate of formation of hippuric acid from hippuryl-L-histidyl-Lleucine (HHL) (Puspitojati, 2019; Chusman and Cheung, 1971 with a modification). $50 \mu \mathrm{l}$ of the sample solution and $50 \mu \mathrm{l}$ of ACE solution $(25 \mathrm{mU} / \mathrm{ml})$ were pre-incubated at $37^{\circ} \mathrm{C}$ for $10 \mathrm{~min}$, then the mixture was incubated with 50 $\mu$ l substrate (Hip-His-Leu $8 \mathrm{mM}$ in $50 \mathrm{mM}$ HEPES buffer containing $300 \mathrm{mM} \mathrm{NaCl}$ at $\mathrm{pH}$ 8.3) for $30 \mathrm{~min}$ at the same temperature. The reaction was ended with the addition of 1 $\mathrm{M} \mathrm{HCl}(200 \mu \mathrm{l})$. The solution was extracted by the addition of $1.5 \mathrm{ml}$ of ethyl acetate and the mixture was stirred for 2 $\mathrm{min}$ and then centrifuged $(4000 \mathrm{xg})$ for $15 \mathrm{~min}$. One $\mathrm{ml}$ of the supernatant was transferred to another glass tube and evaporated in boiling water for $30 \mathrm{~min}$. The resulting dry sample was then dissolved in $3 \mathrm{ml}$ of distilled water and absorbance was measured at $\mathrm{l}=228 \mathrm{~nm}$ using a UV-VIS spectrophotometer.

ACE I activity is calculated as the percentage inhibition of ACE activity using the formula:

$$
\% \text { inhibition }=((\mathrm{A}-\mathrm{B})) /((\mathrm{A}-\mathrm{C})) \times 100 \%
$$

Where :

$\mathrm{A}=$ absorbance of the ACE enzyme and substrate

$\mathrm{B}=$ sample absorbance $+\mathrm{ACE}+$ substrate enzyme

$\mathrm{C}=$ absorbance of substrate + sample

\section{IC50 Value Determination}

The IC50 value was determined based on the relationship of linear curves between ACE inhibitory activity values $(\%)$ and the concentration of protein hydrolyzates from the sample.

\section{Peptide Fractionation}

Peptide fractionation by dialysis technique referred to Pohl (1990). The sample of $10 \mathrm{ml}$ was inserted into the membrane bag (Molecular Weight Cut Off $1 \mathrm{kDa}, 3.5 \mathrm{kDa}$, and $14 \mathrm{kDa}$ ). Then the bag was soaked in aquabides at a ratio between the peptides and aquabides 1:9. Dialysis was carried out for an overnight in the cold room. The resulting peptide fraction was then lyophilized.

\section{RESULT AND DISCUSSION Proximate Koro kratok beans}

The proximate analysis of koro kratok seeds can be seen in Table 1 . The protein content $(20.66 \%)$ was within the range protein content of koro kratok reported by Maesan and Somaatmadja (1993) (18-25\%). Just like protein, the fat content of koro kratok in this study was also within the range of fat content reported by Maesan and Somaatmadja (1993) (0.2-3\%). These data indicated that koro kratok was a source of protein that has the potential to become a peptide after fermentation.

Table 1. Proximate of koro kratok seeds (Phaseolus lunatus)

\begin{tabular}{lc}
\hline \multicolumn{1}{c}{ Component } & $\%$ \\
\hline Moisture content & $12.04 \pm 0.07$ \\
Ash content & $3.97 \pm 0.17$ \\
Lipid content & $1.28 \pm 0.01$ \\
Protein content & $20.66 \pm 0.24$ \\
Carbohydrate by difference & $62.71 \pm 0.50$ \\
\hline
\end{tabular}

\section{Amino Acid Composition}

Table 2 shows the amino acid composition of koro kratok. leucine content was the highest among the hydrophobic amino acids. This amino acid had a strong effect on ACE bonding (Daskaya-Dikmen et al., 2017). As seen in Table 2 , the content of hydrophilic amino acids was higher than hydrophobic ones.

Table 2. Amino acid composition of koro kratok seeds (Phaseolus lunatus)

\begin{tabular}{ll}
\hline Amino acids content & $\%(\mathrm{~g} / 100 \mathrm{~g}$ protein $)$ \\
\hline Alanine & 0.51 \\
Glycine & 0.49 \\
Valine & 0.45 \\
Leucine & 0.71 \\
Isoleucine & 0.36 \\
Proline & 0.34 \\
Phenylalanine & 0.41 \\
Methionine & 0.03 \\
Cysteine & 0.02 \\
\hline Hydrophobic Amino Acids & 3.32 \\
\hline Aspartic acid & 0.94 \\
Glutamic acid & 1.18 \\
Arginine & 4.40 \\
Lycine & 0.40 \\
Histidine & 0.27 \\
Serine & 0.70 \\
Threonine & 0.45 \\
Tyrosine & 0.13 \\
\hline Hydrophilic Amino Acids & 8.47 \\
\hline
\end{tabular}

The amino acid of arginine was dominant in the hydrophilic amino acids group. L-arginine could be converted to nitric oxide by the enzyme nitric oxide synthase so that it has the potential to be a vasodilator (Lee and Hur 2017). 


\section{ACE Inhibitory Activity}

Bioactive peptides that have ACE inhibitory activity were expressed as percentage inhibition of ACE. ACE inhibition activity in non-fermented koro seeds as control and koro kratok tempeh shown in Table 3.

Table 3. Inhibitory ACE activity in non-fermented and koro kratok tempeh

\begin{tabular}{lll}
\hline Sample & Inhibitory ACE Activity $(\%)$ & $\mathrm{IC}_{50}(\mathrm{mg} / \mathrm{mL})$ \\
\hline Non-Fermented & $24.1 \pm 8.5$ & 1.86 \\
Tempeh & $85.0 \pm 2.9$ & 0.763 \\
\hline
\end{tabular}

ACE inhibitory activity was detected in non-fermented koro kratok, which was $24.1 \%$. This inhibitory activity may be caused by the presence of small molecular weights of peptides (14-18 $\mathrm{kDa}$ ) which were naturally present in the seed (Chel-Guerrero et al., 2007). These bioactive peptides can be found in food ingredients as natural ingredients or as hydrolyzate products (Malaguti et al., 2014).

ACE inhibitory activity in koro kratok tempeh was $85.0 \%$, increased compared to non-fermented seeds. This increase could be understood because, during fermentation, the protein was hydrolyzed to the small peptide by protease produced by the mold of Rhizopus oligosphorus. These peptides may possess ACE inhibitory activity.

ACE inhibitory peptides are affected by hydrophobic amino acids. Koro kratok tempeh has a hydrophobic amino acid composition of $4.78 \mathrm{~g} / 100 \mathrm{~g}$ protein with. According to Pan et al. (2011), the mechanism of inhibition of ACE activity was as followed: the active site of ACE was bond to amino acid residues in peptides through hydrogen bonding, hydrophobic interactions, hydrophilic interactions, electrostatic interactions, or $\mathrm{Zn}^{2+}$ binding. Besides, the size of the peptide will also influence the ACE inhibitory activity. Some researchers reported that peptides having ACE inhibitory activity can be dipeptide (Pan et al., 2011, tripeptides (Pan et al., 2011), heptapeptides (Toopcham et al., 2015) and oligopeptides (Balti et al., 2015). These peptides might be formed during koro kratok tempeh fermentation so that resulted in a higher ACE inhibitory activity compared to that non-fermented.

Koro kratok tempeh has a smaller $\mathrm{IC}_{50}$ value compared to non-Lermented koro kratok, which was $0.763 \mathrm{mg} / \mathrm{mL}$ (Table 3). This $\mathrm{IC}_{50}$ value was still bigger compared to the koro kratok which was hydrolyzed for $90 \mathrm{~min}$ using alcalase and Flavourzy, each of 0.056 and $0.0069 \mathrm{mg} / \mathrm{mL}$, respectively (Uco et al., 2009).

\section{ACE Inhibitory Activity on Fractionation of Peptide Tempeh Koro Kratok}

The tempeh peptides were fractionated using the dialysis method. The fraction obtained was then analyzed for ACE inhibitory activity and the results were shown in Figure 1.

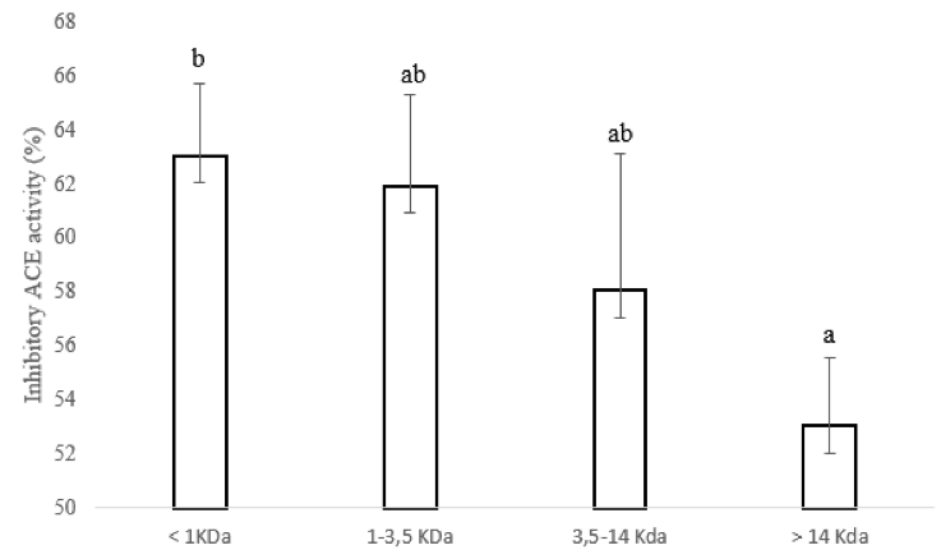

Figure 1. ACE inhibitory activity of peptide fraction from koro kratok tempeh

Figure 1. shows peptides having a molecular weight (MW) less than $1 \mathrm{kDa}$ had ACE inhibitory activity of $63.06 \%$, whereas fractions with MW of 1-3.5 kDa, 3.5-14 kDa, and more than $14 \mathrm{kDa}$ had an inhibitory activity of $61.94 \%$, $58.06 \%$, and $53.06 \%$ respectively. The results of this study indicate that the smaller the MW of the peptide, the greater the ACE inhibitor activity. The results of this study were similar to that of Natesh et al. (2003); Toopcham et al. (2014); Darewicz et al. (2014); Power et al. (2014) which they stated that fractions with small MW peptides have high ACE inhibitory activity.
The results of this study indicate that the smaller the MW of the peptide the greater the inhibitory activity. Natesh et al. (2003) state that long-chain peptides are more difficult to bind to the active site of ACE so that reduced ACE inhibitory activity. This is in line with the statement of Tamam et al. (2018) that peptides that have ACE inhibitory activity have a smaller peptide chain and MW than other peptides. However, statistical calculation indicated that the fractions of $\mathrm{MW}<1 \mathrm{kDa}$ not significantly differed $(\mathrm{p}<0.05)$ from the peptide fraction of MW between $1-3.5 \mathrm{kDa}$ and $3.5-14 \mathrm{kDa}$. The results of this study are supported by 
the results of previous studies that the MW of peptides which have the highest ACE inhibitory activity ranges from 200 - 850 Da (Wang et al., 2017; Sornwatana et al., 2015; Moayedi et al., 2018; Lee et al., 2004; White et al., 2014).

\section{CONCLUSION}

Koro kratok tempeh has the potential to be a source of bioactive peptides because of protein content and amino acid composition. The fermentation could increase the ACE inhibitory activity because fermentation hydrolyzed protein to become small peptides. Low molecular weight peptides contained in the koro kratok tempeh had higher ACE inhibitory activity.

\section{Acknowledgment}

The authors wish to thank The Ministry of Research, Technology and Higher Education, the Republic of Indonesia for supporting this project through the Postgraduate Team Project (Proyek Tim Pasca) 2018.

\section{REFERENCES}

AOAC. Official Methods of Analysis of the Association of Official Analytical Chemists, 16th Een. Washington DC: AOAC (2005).

Balti R., Bougatef A., Sila A., Guillochon D., Dhulster P., NedjarArroume N. (2015). Nine Novel Angiotensin I-Converting Enzyme (ACE) Inhibitory Peptides from Cuttle Fish (Sepia officinalis) Muscle Protein Hydrolysates and Antihypertensive Effect of the Potent Active Peptide in Spontaneously Hypertensive Rats, FoodChem. 170 : 519-525.

Baudoin JP, Rocha O, Degreef J, Maquet A, Guarino L. (2004). Ecogeography, Demography, Diversity and Conservation of Phaseolus lunatus L. In the Central Valley of Costa Rica. In: Sysematic and Ecogeographic Studies on Crop Genepools 12. International Plant Genetic Resource Institute [IPGRI], Roma, Italy.

Budi Widianarko, Rika Pratiwi, Soedarini, Rossana Dewi, Sri Wahyuningsih, danNunik Sulistiyani. (2003). Menuai Polong, Sebuah Pengalaman Advokasi Keragaman Hayati. Gramedia Widiasarana. Jakarta.

Bujang, A., and Nurul A.T. (2014). Change on Amino Acid Content in Soybean, Garbamzo Bean and Groundnut During Pre-treatment and Tempeh Making. Sains Malaysiana, 43(4), 551-557.

Chel-Guerrero, L., Adriana A. S., Santiago G. T., Gloria D., and Maria C. A. (2007). Physicochemical and Structural Characterization of Ilma Bean (Phaseolus lunatus) Globulins. LWT, 40 : 1537-1544.

Cushman DW, Cheung HW. (1971). Spectrophotometric Assay and Properties of the Angiotensin Converting Enzyme of the Rabbit Lung. Biochem Pharmacol 20:1637 - 1648.

Darewicz, M., Borawska J., Vegarud G. E., Minkiewicz P., and Iwaniak A. (2014). Angiotensin I-Converting Enzyme (ACE) Inhibitory Activity An ACE Inhibitory Peptides of Salmon (Salmo salar) Protein Hydrolysates Obtained by Human and Porcine Gastrointestinal Enzymes. International Journal of Molecular Sciences, 15, 1407714101.

Daskaya-Dikmen, C. et al. (2017) 'Angiotensin-I-converting enzyme (ACE)-inhibitory peptides from plants', Nutrients, 9(4), pp. 1-19. doi: 10.3390/nu9040316.

Deddish, P.A., Wang, J., Michel, B., Morris, P.W., Davidson, N.O., Skidgel, R.A., Erdös, E.G. 1994. Naturally Occurring Active N-Domain of Human Angiotensin I-Converting Enzyme. Proc. Natl. Acad. Sci. 91, 7807-7811.

Karmini, M., Sutopo, D., dan Hermana. 1996. Aktivitas Enzim Hidrolik Kapang Rhizopus sp pada Proses Fermentasi Tempeh. Penelitian Gizi dan Makanan 19:93-102.

Lee, D.H., Kim J.H., Park J.S., Choi Y.J., Lee J.S. 2004. Isolation and Characterization of a Novel Angiotensin I-Converting Enzyme Inhibitory Peptide Derived from the Edible Mushroom Tricholoma Giganteum. Peptides, 25, 621-627.

Lee, S. Y. and Hur, S. J. (2017) 'Antihypertensive peptides from animal products, marine organisms, and plants', Food Chemistry. Elsevier Ltd, 228, pp. 506-517. doi: 10.1016/j.foodchem.2017.02.039.

LuoAs I.M., Alexander B.M., Oliveira M. M., Abreu I.A. 2016. Selection of An Appropriate Protein Extraction Method to Study the Phosphoproteome of Maize Photosynthetic Tissue. PLOS ONE 11(10): e) 164387.

Maesan, V. D dan Somaatmadja S. 1993. Proses Sumber Daya Nabati Asia Tenggara. Jakarta : Penerbit Gramedia Pustaka Utama.

Magana, M.D., Maira S.C., Gloroa D.O., David B.A., Luis C.G. 2015. ACE-I Inhibitory Properties of Hydrolysates from Germinated and Ungerminated Phaseoulus lunatus Proteins. Food Science and Technology 35(1): 167-174.

Malaguti, M., Dinelli, G., Leoncini, E., Bregola, V., \& Bosi, S. (2014). Bioactive Peptides in Cereals and Legumes: Agronomical, Biochemical and Clinical Aspects, 21120-21135. https://doi. org/10.3390/ijms151121120.

Mechin V., Damerval C., Zivy M. 2007. Total Protein Extraction with TCA-Acetone. In: Thiellement H, Zivy M., Damerval C., Mechin V., Editors. Plant Proteomics: Methods and Protocols. Methods in Molecular Biology. 355. New Jersey: Humana Press.

Moayedi, A., Mora L., Aristoy M.C., Hashemi M. Safari M., Toldrá F. 2018. ACE-Inhibitory and Antioxidant Activities of Peptide Fragments Obtained from Tomato Processing By-Products Fermented Using Bacillus Subtilis: Effect of Amino Acid Composition and Peptides Molecular Mass Distribution. Appl. Biochem. Biotechnol, 181, 48-64.

Natesh R., Schwager SL., Sturrock ED, Asharya KR. 2003. Crystal Structure of the Human Angiotensin-Converting Enzyme-Lisinopril Complex, Nature, 421 (6922): 551-4.

Nout, M.J.R., Kiers J.L. 2005. Tempeh Fermentation, Innovation and Functionality: Update Into the Third Millennium. Journal of Applied Microbiology 98: 789-805.

Pan, D., Huiqing G., Bo Z., Jinxuan C. 2011. The Molecular Mechanisms of Interactions Between Bioactive Peptides and AngiotensinConverting Enzyme. Bioorganic \& Medicinal Chemistry Letter 21: 3898-3904.

Pohl, T. 1990. Concentration of Protein Removal of Salute dalam M.P. Deutscher, Methods of Enzymology: Guide to Protein Purification. Vol: 182. Academic Press. New York.

Power, O., Fernández A., Norris R., Riera F. A., and FitzGerald R. J. 2014. Selective Enrichment of Bioactive Properties during Ultrafiltration of A Tryptic Digest of $\beta$-lactoglobulin. Journal of Functional Foods, 9, $38-47$.

Sornwatana, T., Bangphoomi K., Roytrakul S., Wetprasit N., Choowongkomon K., Ratanapo S. 2015. Chebulin: Terminalia Chebula Retz. Fruit-Derived Peptide with Angiotensin-I-Converting Enzyme Inhibitory Activity. Biotechnol. Appl. Biochem, 62, 746753.

Stephanie, and Purwadaria T. 2013. Fermentasi Substrat Padat Kulit Singkong Sebagai Bahan Pakan Ternak Unggas. Wartazoa. 23:15-22.

Tamam B., Dahrul S., Hanifah N. L., Maggy T. S., and Wisnu A. K. 2018. Beberapa Penciri Berbasis Sekuens Untuk Mengenali Sifat Fungsional Peptida Bioaktif : Studi Eksplorasi. J. Teknol. Dan Industri Pangan, 29 (1), 1-9.

Tejasari. 2016. Protein Density and Quality of Koro kratok (Phaseolus lunatus L. Sweet) and Kacang Tunggak (Vurga unguiculata (L) Walp). Proceeding ICMHS. ISBN 978-602-60569-3-1.

Toopcham, T., Sittiruk R., Jirawat Y. 2015. Characterization and Identification of Angiotensin I-Converting Enzyme (ACE) Inhibitory Peptides Derived from Tilapia Using Virgibacillus Halodenitrificans SK1-3-7 proteinases. Journal of Functional Foods, 14: 435 - 444.

Uco, J.T., Luis C.G., Alma M.A., Gloria D.O., David B.A., 2009. Angiotensin-I Converting Enzyme Inhibitory and Antioxidant Activities of Protein Hydrolysates from Phaseolus lunatus and Phaseolus vulgaris seeds. Food Science and Technology, 42: 15971604.

Wang, C., Ma, Q., Pagadala, S., Serrard, M.S., adn Krishnan, P.G. 1998. Changes of During Processing of Soybean Protein Isolates. J. Am. Oil Chem. Soc. 75: 337-341.

Wang, X., Chen H., Fu X., Li S.,Wei J. 2017. A Novel Antioxidant and ACE-Inhibitory Peptide from Rice Bran Protein: Biochemical 
Characterization and Molecular Docking Study. LWT-Food Sci. Technol, 75, 93-99.

White, B. L., Sanders T. H., Davis J. P. 2014. Potential ACE-Inhibitory Activity and Nano-LC-MS/MS Sequencing of Peptides Derived from Aflatoxin Contaminated Peanut Meal. LWT-Food Sci. Technol, 56, $537-542$. 